\title{
Postmortem changes in physiochemical and sensory properties of red snow crab (Chionoecetes japonicus) leg muscle during freeze storage
}

\author{
Joon-Young Jun ${ }^{1}$, Min-Jeong Jung ${ }^{1}$, Dong-Soo Kim², In-Hak Jeong ${ }^{3}$ and Byoung-Mok Kim
}

\begin{abstract}
In order to evaluate the maximal storable period of the raw crab for a non-thermal muscle separation, the quality changes of the leg meat of red snow crab (Chionoecetes japonicus) during freeze storage were investigated. Fresh red snow crabs were stored at $-20^{\circ} \mathrm{C}$ for 7 weeks, and the leg muscle was separated by a no heating separation (NHS) method every week. During the storage, considerable loss of the leg muscle did not occur and microbiological risk was very low. In contrast, discoloration appeared at 2-week storage on around carapace and the leg muscle turned yellow at storage 3week. In physiochemical parameters, protein and free amino acids gradually decreased with storage time, expected that proteolytic enzymes still activated at $-20^{\circ} \mathrm{C}$. At 4-week storage, the sensory acceptance dropped down below point 4 as low as inedible and notable inflection points in $\mathrm{pH}$ and acidity were observed. The volatile base nitrogen was low, though a little increase was recorded. These results suggested that the maximal storable period at $-20^{\circ} \mathrm{C}$ of the raw material was within 2 weeks and it was depended on external factor such as the discoloration. The present study might be referred as basic data for approaches to solve quality loss occurred in non-thermal muscle separation.
\end{abstract}

Keywords: Red snow crab, Chionoecetes japonicus, Postmortem change, Leg muscle, Non-thermal muscle separation

\section{Background}

Red snow crab (Chionoecetes japonicus) belongings to Malacostraca, has an innate red color and inhabits a cold seawater in depth of 500 to 23,000 $\mathrm{m}$ in the East Sea of the Korean coast (Park et al. 2003). This crab is very popular in Korean market because of its unique flavor and taste (fresh, sweet, and umami). Since the red snow crab is caught all year round stably except a close season (July to August) with the total allowable catch (KFA 2015) and low priced, the crab may be a potential resource in the term of food industry. Unfortunately, industrial utilization is low.

In food industry, the red snow crab has been mainly produced and distributed into frozen meats (leg and body) or meat flake through muscle separation process after boiling with water (Kim et al. 2005). For the meat production, the boiling process is necessary as a pre-processing

\footnotetext{
* Correspondence: bmkim@kfri.re.kr

'Division of Strategic Food Industry Research, Korea Food Research Institute, Seongnam 13539, Republic of Korea

Full list of author information is available at the end of the article
}

for preservation from the spoilage induced by enzymes and micro-organism, but in which some problems, such as waste water, loss of nutritional components and high energy cost have been raised. However, it is very difficult to separate the muscles from the shells of body and legs intactly without the boiling process (Ahn et al. 2006).

In recent, Kim et al. (2015) suggested a no heating separation (NHS) method for separating leg muscle using a miller machine equipped with multilayered roller, which can separate without the external damage of the leg muscle, and they investigated the effects of storage temperature and thawing condition on the meat quality with the NHS method. Although spoilage rate of fish muscle varies on their species, the postmortem bio-degradation of the red snow crab muscle is obviously occurred even in freeze storage. In other reports, the protein solubility of the muscles from hard and soft shell mud crabs (Scylla serrata) gradually decreased during storage at $-20{ }^{\circ} \mathrm{C}$ and a notable $\mathrm{pH}$ variation was also found (Benjakul and Sutthipan 2009). Matsumoto and Yamanaka (1992) reported that ATP and 
glycogen in the leg muscle from snow crab (Chionoecetes opilio) reduced quickly and the volatile base nitrogen reached the initial spoilage level $(25 \mathrm{mg} \%)$ within 7 days when stored at $-1{ }^{\circ} \mathrm{C}$.

The quality loss of seafood is affected by many external factors, such as storage temperature and period, packaging, and rate of freezing and thawing (Srinivasan et al. 1997). For assessment of fish quality, Food and Agriculture Organization (FAO) of the United Nations recommended sensory, chemical, physical, and microbiological tests, in which appearance, odor, nitrogenous compounds, nucleotide catabolites, glyco-metabolites, $\mathrm{pH}$, and spoilage, and pathogenic bacteria are included (Huss 1995). The purpose of this study is to suggest the maximal storable period for muscle separation from red snow crab (C. japonicus) during freeze storage through investigation of the postmortem quality changes in the leg muscle during storage at $-20{ }^{\circ} \mathrm{C}$ with the NHS method. The present study might be referred as basic data for approaches to solve quality loss occurred in non-thermal muscle separation.

\section{Methods}

\section{Materials and preparation of sample}

About 30 of live male red snow crab (C. japonicus) with body weight and total length of $577.8 \pm 118.1 \mathrm{~g}$ and 73.2 $\pm 6.4 \mathrm{~cm}$ were used in this study, which were purchased from the Jumunjin fishery market (Gangneung, Republic of Korea). The crab was transported in ice to our laboratory immediately, rinsed with a pure water to eliminate debris, and stored at $-20{ }^{\circ} \mathrm{C}$ in a polystyrene icebox. For leg muscle separation, the no heating separation (NHS) method of recommended by Kim et al. (2015) was employed. Briefly, the crab was thawed at $0{ }^{\circ} \mathrm{C}$ for $20 \mathrm{~s}$, and the leg part was cut (Fig. 1) and passed through between the multilayered roller of miller machine (YMC103; YongMa Machinery, Daegu, Republic of Korea) to separate the leg muscle.

\section{Appearance and color}

The appearance of the crab body and leg muscle collected in different storage period was photographed using a phone camera (Iphone 6S, Apple Inc., Cupertino, CA, USA). The color (Hunter's $L, a$, and $b$ values) of the leg muscle was measured using a chroma meter (CR300; Minolta Co. Ltd., Osaka, Japan).

\section{Proximate composition and salinity}

Moisture, ash, crude protein, and crude lipid of the leg muscle were measured according to the AOAC method (AOAC 2005). Carbohydrate was calculated as follows: "100\% - (moisture\% + ash $\%$ + crude protein $\%$ + crude lipid\%)". For salinity determination, the sample was burned at $550{ }^{\circ} \mathrm{C}$ for $6 \mathrm{~h}$ to eliminate organic compounds and the ash was diluted in deionized water (DW). The salinity of the diluted sample was determined by volumetric titration with $\mathrm{AgNO}_{3}$ using Mohr's method (Feng et al. 2012).

\section{Free amino acid}

For free amino acid analysis, $10 \mathrm{~g}$ of the sample was mixed with $100 \mathrm{~mL}$ of $75 \%$ ethanol, homogenized at $11,000 \mathrm{rpm}$ for $30 \mathrm{~s}$ and centrifuged at $6000 \times \mathrm{g}$ for $10 \mathrm{~min}$. The supernatant was collected, and the residue

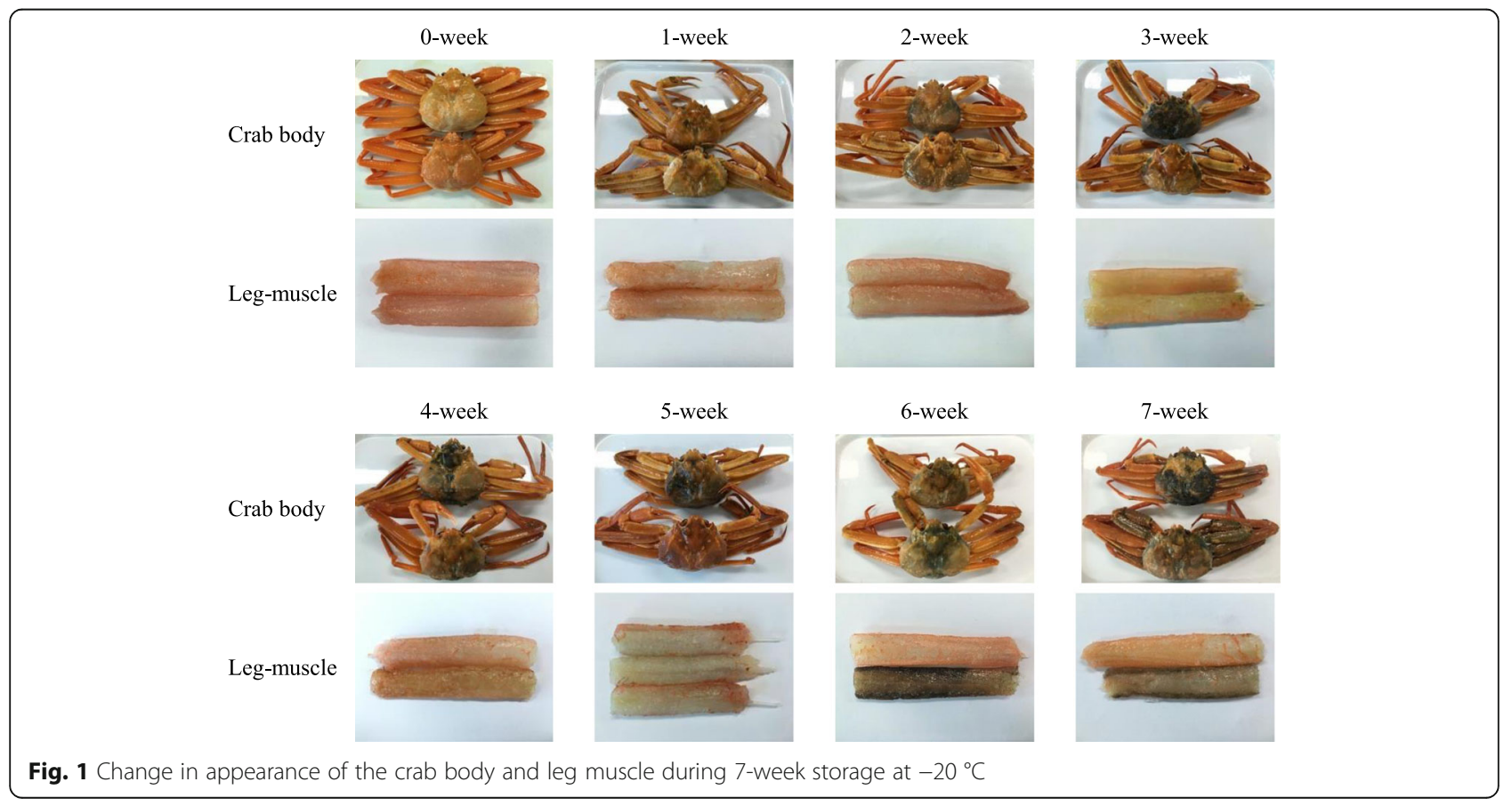


was mixed again with $100 \mathrm{~mL}$ of $75 \%$ ethanol to extract remain amino acid. After homogenization and centrifugation, the solvent in the collected supernatant was eliminated using a rotary evaporator. The final dried sample was dissolved in DW and filtrated using a $0.45-$ $\mu \mathrm{m}$ MCE syringe filter unit before analysis. The amino acids were analyzed using a high-speed amino acid analyzer (L-8800; Hitachi High-Technologies Co., Tokyo, Japan), according to the method of Kim et al. (2016).

\section{$\mathrm{pH}$, titratable acidity, and volatile base nitrogen}

For $\mathrm{pH}$ determination, $5 \mathrm{~g}$ of the sample was mixed with $45 \mathrm{~mL}$ of DW, homogenized at 11,000 rpm for $30 \mathrm{~s}$ and centrifuged at $6000 \times g$ for $10 \mathrm{~min}$. The $\mathrm{pH}$ of the supernatant was determined using a $\mathrm{pH}$ meter (SevenEasy S20K; Metteler Toledo International Inc., Columbus, $\mathrm{OH}$, USA). After the $\mathrm{pH}$ determination, $20 \mathrm{~mL}$ of the supernatant was taken and titrated with $0.1 \mathrm{~N} \mathrm{NaOH}$ until $\mathrm{pH}$ 8.3. The acidity was expressed as lactic acid\%. The volatile base nitrogen (VBN) was determined by Conway's diffusion method (Choi et al. 2016).

\section{Bacterial cell count}

Aerobic and lactic acid bacterial cell in the sample were counted by plate count method using two different media. Ten grams of the sample was mixed with $90 \mathrm{~mL}$ of $0.1 \%$ sterile peptone buffered water ( $\mathrm{pH}$ 7.2) and minced using a home blender sterilized with UV irradiation. The minced sample was transferred in a sterile plastic bag and homogenized using a stomacher. The homogenized sample was decimally diluted with $0.1 \%$ sterile peptone buffered water (pH 7.2). A $1 \mathrm{~mL}$ of the dilute was added onto petri-dish, and plate count agar (Difco; Becton Dickinson, Spark, MD, USA) for aerobic bacteria and lactobacilli MRS agar (Difco; Becton Dckinson) for lactic acid bacteria were poured, respectively. After incubation at $35{ }^{\circ} \mathrm{C}$ for $48 \mathrm{~h}$, the viable cells (between 20 and 200 colonies) were counted and expressed as the logarithmic number of colony-forming units per gram sample.

\section{Statistical analysis}

A quantitative descriptive method (Lorentzen et al. 2014) with slight modification was conducted to test the freshness of the leg muscle with 20 non-trained panelists (ten men and ten women, age: 20-30). All panelists were asked to give freshness scores for appearance, texture (not eaten), flavor, and overall acceptance using a 7-point scale in which one represented "poorest quality" and seven represented "best quality."

\section{Sensory test}

All data except free amino acid were expressed as the mean \pm standard deviation (SD) in triplicate. The values were statistically assed by a one-way ANOVA test; a significant difference $(p<0.05)$ between means identified by least significant difference and Tukey's test using SPSS (IBM, Armonk, NY, USA).

\section{Results and discussion \\ Appearance and color}

Figure 1 shows the change in appearance of the crab body and leg muscle during 7 -week storage at $-20^{\circ} \mathrm{C}$. The carapace and legs at 0 -week storage represented an innate white-red color, while of the carapace at 2-week storage changed to black color and it seemed to be expended to legs at 7 -week storage. The leg muscle separated by the NHS method at storage 3-week yellowed compared to that of 0 -week storage. From 5-week storage, surface peeling of the leg muscle was occurred and black color appeared from 6-week storage. On the Hunter's $L, a$, and $b$ values of the leg muscle, $L$ value gradually decreased with storage period except storage 3-week (Table 1). From 4week storage, consistent decreases were found in $a$ and $b$ values. An enzymatic browning frequently appears in crustacean during storage, which is mainly related to phenol-oxidase (tyrosinase) that is responsible for the black discoloration called melanosis and physiologically important because the enzyme is contributed to natural wound healing in part (Kim et al. 2000).

\section{Proximate composition and salinity}

Changes in the proximate composition and salinity of the leg muscle during 7 -week storage at $-20{ }^{\circ} \mathrm{C}$ are listed in Table 2. The leg muscle (0-week storage) was composed of mostly protein $(70.1 \% /$ dry basis, $12.20 \% /$ wet basis), followed by carbohydrate $(16.4 \%$ /dry basis, $2.40 \%$ /wet basis), ash (11.6\%/dry basis, $1.20 \% /$ wet basis), and lipid (1.8\%/dry basis, $0.60 \% /$ wet basis). Although there are seasonal and regional variations, proximate composition of various species of crabs collected in the Republic of Korea have been reported in ranges of moisture 81.4-83.0\%, protein 13.7-15.2\%, lipid $0.5-0.8 \%$, and ash $1.9-2.1 \%$ (NFRDI 2009).

By comparison with these values on dry basis, the red snow crab contained comparatively low protein and high carbohydrate than other crab species. The postmortem biochemical changes in fish muscle are very complex, but which is occurred generally with ATP degradation, glycolysis, rigor, tenderization, autolysis, and putrefaction continuously (Gill 2000). The first changes are initiated with endogenous enzymes promoting proteolysis of the muscle protein and lipid hydrolysis (Delbarre-Ladrat et al. 2006). In this study, no loss was occurred in moisture during 7 -week storage at $-20{ }^{\circ} \mathrm{C}$, but the values varied in ranges of 80.5 to $85.7 \%$. On dry basis, independent changes with storage period were found in ash and carbohydrate, whereas the crude protein gradually decreased with storage period except 5 -week storage and the lipid slightly increased after 2-week storage. 
Table 1 Change in color of the leg muscle during 7 -week storage at $-20^{\circ} \mathrm{C}$

\begin{tabular}{|c|c|c|c|c|c|c|}
\hline \multirow{2}{*}{$\begin{array}{l}\text { Storage time (week) } \\
0\end{array}$} & \multicolumn{2}{|c|}{ L value (lightness) } & \multicolumn{2}{|c|}{$a$ value (redness) } & \multicolumn{2}{|c|}{ b value (yellowness) } \\
\hline & 46.2 & $\pm 1.8^{\mathrm{ab}}$ & 8.5 & $\pm 1.2^{\mathrm{ab}}$ & 4.7 & $\pm 1.0^{\mathrm{ab}}$ \\
\hline 1 & 46.4 & $\pm 2.6^{\mathrm{ab}}$ & 8.4 & $\pm 1.0^{\mathrm{ab}}$ & 9.4 & $\pm 3.0^{\mathrm{a}}$ \\
\hline 2 & 43.8 & $\pm 1.5^{\mathrm{bc}}$ & 10.4 & $\pm 0.8^{\mathrm{a}}$ & 6.2 & $\pm 2.9^{\mathrm{ab}}$ \\
\hline 3 & 51.8 & $\pm 3.0^{\mathrm{a}}$ & 6.5 & $\pm 1.4^{\mathrm{ab}}$ & 7.2 & $\pm 2.5^{\mathrm{ab}}$ \\
\hline 4 & 42.9 & $\pm 2.0^{\mathrm{bc}}$ & 8.2 & $\pm 1.8^{\mathrm{ab}}$ & 8.0 & $\pm 3.8^{\mathrm{a}}$ \\
\hline 5 & 41.4 & $\pm 1.2^{\mathrm{bc}}$ & 7.9 & $\pm 3.2^{\mathrm{ab}}$ & 5.8 & $\pm 2.0^{\mathrm{ab}}$ \\
\hline 6 & 43.2 & $\pm 2.2^{\mathrm{bc}}$ & 6.6 & $\pm 1.8^{\mathrm{ab}}$ & 6.4 & $\pm 1.4^{\mathrm{ab}}$ \\
\hline 7 & 37.9 & $\pm 2.6^{c}$ & 4.6 & $\pm 1.4^{\mathrm{b}}$ & 2.5 & $\pm 1.7^{\mathrm{b}}$ \\
\hline
\end{tabular}

Data expressed as the mean \pm SD $(n=3)$. Different types of small superscript letters indicate significantly differences $(p<0.05)$

Freeze storage is an important preservation method, and it slows enzyme activity and micro-organism growth, but the rate of the protein degradation relies on fish species (Srinivasan et al. 1997) and especially in case of crustacean, the proteolysis occurred in ice obviously. The salinities of the leg muscle during 7-week storage were in ranges of $1.6-2.4 \%$ (wet basis), and there were not much changes.

\section{Free amino acid}

Table 3 shows change in the free amino acid profile. In total, 13 types of composite amino acids were detected, including most essential amino acids except histidine. Amino acids below the detection limit were not indicated. The total content of free amino acid at 0 -week storage was $2390.9 \mathrm{mg} \%$ (wet basis), which accounted for approximately $20 \%$ of the crude protein $(11,500.0 \mathrm{mg} \%$, wet basis).

The free amino acid composition of the C. japonicus is close to general crabs, which contain taurine, proline, glycine, alanine, and arginine as the major amino acids (NFRDI 2009). During 7-week storage, the total content decreased and consistent decreases were found in glycine, tyrosine, and arginine. In Matsumoto and Yamanaka (1992) report, total content of free amino acid in the leg muscle from $C$. opilio have been determined to $2261 \mathrm{mg} \%$ and it was decreased gradually with storage time when stored at $0{ }^{\circ} \mathrm{C}$, but the composition was not similar to that of the C. japonicus. Decomposition of proteins and amino acids by enzymes increases $\mathrm{NH}_{3}$ and amines, also increases VBN content and $\mathrm{pH}(\mathrm{Xu}$ et al. 2008). Namely, it is considered that the free amino acid contents decreased due to the VBN content and $\mathrm{pH}$ were increased by excessive decomposition of amino acids at 7-day storage.

\section{$\mathrm{pH}$, acidity, and volatile base nitrogen}

Figure 2 displays the changes in $\mathrm{pH}$, acidity, and volatile base nitrogen (VBN). During 7-week storage, notable inflection points in both of $\mathrm{pH}$ and acidity were observed at 4-week storage. In more detail, the initial $\mathrm{pH}$ value (7.41) decreased until pH 7.05 at storage 3-week and tended to increase from 4-week storage. In contrast, the acidity increased during storage 3-week and subsequently decreased. $\mathrm{pH}$ change in fish occurs during storage or fermentation, which is affected by formation of organic acid and base nitrogen (Jun et al. 2016). In VBN, no considerable change was found and the values were in ranges of 11.9 to $18.3 \mathrm{mg} \%$ (wet basis). The increase of the $\mathrm{pH}$ in the leg muscle during freeze storage could be strongly associated with the formation of organic acid than VBN.

Miyagawa et al. (1990) studied that the changes in the free amino acid profile of $C$. opilio muscle during storage in ice for 28 days. In their report, the $\mathrm{pH}$ decreased until day 3 storage and increased in which term enzymes were

Table 2 Changes in proximate composition and salinity of the leg muscle during 7-week storage at $-20^{\circ} \mathrm{C}$

\begin{tabular}{|c|c|c|c|c|c|c|c|c|c|c|}
\hline $\begin{array}{l}\text { Storage period } \\
\text { (week) }\end{array}$ & $\begin{array}{l}\text { Moisture } \\
\text { (\%, wet basis) }\end{array}$ & $\begin{array}{l}\text { Ash } \\
\text { (\%, dry/wet) }\end{array}$ & & $\begin{array}{l}\text { Lipid } \\
\text { (\%, dry/wet) }\end{array}$ & & $\begin{array}{l}\text { Protein } \\
(\%, \text { dry/wet })\end{array}$ & & $\begin{array}{l}\text { Carbohydrate } \\
\text { (\%, dry/wet) }\end{array}$ & & $\begin{array}{l}\text { Salinity } \\
(\%, \text { wet basis) }\end{array}$ \\
\hline 0 & $83.6 \pm 0.3^{b}$ & $11.6 \pm 1.0^{a}$ & $/ 1.20$ & $1.8 \pm 0.7^{b c}$ & 10.60 & $70.1 \pm 0.7^{a}$ & $/ 12.20$ & $16.4 \pm 2.0^{d}$ & $/ 2.40$ & $2.1 \pm 0.2^{\mathrm{ab}}$ \\
\hline 1 & $81.8 \pm 0.4^{c}$ & $8.3 \pm 0.4^{b}$ & $/ 1.51$ & $0.8 \pm 0.3^{c}$ & $/ 0.15$ & $70.5 \pm 2.0^{\mathrm{a}}$ & $/ 12.84$ & $20.4 \pm 2.4^{b c d}$ & /3.72 & $1.7 \pm 0.2^{b}$ \\
\hline 2 & $81.7 \pm 0.1^{c}$ & $8.0 \pm 1.1^{b}$ & $/ 1.47$ & $0.7 \pm 0.2^{c}$ & 10.12 & $70.6 \pm 1.8^{\mathrm{a}}$ & $/ 12.91$ & $20.7 \pm 3.3^{\mathrm{bcd}}$ & /3.79 & $1.6 \pm 0.3^{b}$ \\
\hline 3 & $80.7 \pm 0.2^{d}$ & $8.0 \pm 1.2^{b}$ & $/ 1.54$ & $1.0 \pm 0.4^{c}$ & 10.20 & $69.4 \pm 1.2^{\mathrm{a}}$ & $/ 13.39$ & $21.6 \pm 2.7^{\mathrm{bcd}}$ & $/ 4.16$ & $2.0 \pm 0.2^{\mathrm{ab}}$ \\
\hline 4 & $81.5 \pm 0.1^{c}$ & $9.0 \pm 0.2^{b}$ & $/ 1.66$ & $1.4 \pm 0.1^{b c}$ & 10.26 & $66.5 \pm 0.4^{a}$ & $/ 12.29$ & $23.2 \pm 1.7^{\mathrm{abc}}$ & $/ 4.29$ & $2.0 \pm 0.3^{\mathrm{ab}}$ \\
\hline 5 & $80.5 \pm 0.4^{d}$ & $7.9 \pm 0.2^{b}$ & $/ 1.55$ & $1.5 \pm 1.0 \mathrm{bc}$ & 10.29 & $72.3 \pm 2.3^{\mathrm{a}}$ & $/ 14.12$ & $18.3 \pm 1.5^{\mathrm{cd}}$ & /3.58 & $2.0 \pm 0.2^{\mathrm{ab}}$ \\
\hline 6 & $85.1 \pm 0.0^{\mathrm{a}}$ & $13.3 \pm 0.6^{a}$ & $/ 1.98$ & $2.7 \pm 0.2^{a b}$ & 10.40 & $55.9 \pm 3.8^{b}$ & $/ 8.31$ & $27.5 \pm 2.6^{\mathrm{a}}$ & $/ 4.16$ & $2.1 \pm 0.3^{\mathrm{ab}}$ \\
\hline 7 & $84.8 \pm 0.2^{\mathrm{a}}$ & $12.8 \pm 0.1^{\mathrm{a}}$ & $/ 1.94$ & $3.8 \pm 0.1^{a}$ & $/ 0.58$ & $57.5 \pm 3.7^{b}$ & $/ 8.74$ & $25.9 \pm 2.4^{\mathrm{ab}}$ & /3.94 & $2.4 \pm 0.2^{\mathrm{a}}$ \\
\hline
\end{tabular}

Data expressed as the mean \pm SD $(n=3)$. Different types of small superscript letters indicate significantly differences $(p<0.05)$ 
Table 3 Free amino acid profile of the leg muscle during 7-week storage at $-20^{\circ} \mathrm{C}$

\begin{tabular}{|c|c|c|c|c|c|}
\hline \multirow[t]{2}{*}{ Amino acid } & \multicolumn{5}{|c|}{ Storage period (week) } \\
\hline & 0 & 1 & 3 & 5 & 7 \\
\hline \multicolumn{6}{|c|}{ Nutritionally non-essential amino acid (mg $100 \mathrm{~g}^{-1}$, wet base) } \\
\hline Alanine & 270.9 & 264.5 & 278.4 & 264.3 & 176.0 \\
\hline Aspartic acid & 1.2 & 3.9 & 4.8 & 4.2 & 5.3 \\
\hline Glutamic acid & 26.0 & 21.2 & 10.7 & 26.9 & 26.6 \\
\hline Glycine & 657.0 & 582.8 & 562.8 & 450.1 & 359.3 \\
\hline Tyrosine & 59.1 & 20.9 & 31.7 & 19.5 & 20.0 \\
\hline Sum & 1014.2 & 893.3 & 888.4 & 765.0 & 567.2 \\
\hline \multicolumn{6}{|c|}{ Nutritionally essential amino acid (mg $100 \mathrm{~g}^{-1}$, wet base) } \\
\hline Threonine & 1.3 & 7.0 & 18.3 & 5.1 & 21.5 \\
\hline Valine & 58.1 & 46.2 & 59.4 & 56.2 & 53.2 \\
\hline Methionine & 60.5 & 33.4 & 43.1 & 59.6 & 47.9 \\
\hline Isoleucine & 53.3 & 37.3 & 36.8 & 50.6 & 39.1 \\
\hline Leucine & 68.9 & 52.3 & 44.4 & 65.4 & 72.8 \\
\hline Phenylalanine & 61.8 & 39.1 & 51.0 & 42.0 & 36.6 \\
\hline Lysine & 91.7 & 83.0 & 93.2 & 121.1 & 71.7 \\
\hline Arginine & 672.6 & 609.3 & 293.3 & 387.2 & 231.2 \\
\hline Sum & 1068.2 & 907.6 & 639.5 & 787.2 & 573.7 \\
\hline \multicolumn{6}{|c|}{ Other amino acid (mg $100 \mathrm{~g}^{-1}$, wet base) } \\
\hline Phosphoserine & 3.8 & 8.8 & 4.5 & 6.8 & 5.3 \\
\hline Taurine & 210.0 & 172.7 & 192.9 & 182.6 & 135.0 \\
\hline Sarcosine & 75.1 & 58.7 & 68.7 & 47.2 & 53.8 \\
\hline Ammonia & 19.7 & 12.2 & 7.6 & 9.8 & 12.7 \\
\hline Sum & 308.6 & 252.4 & 273.7 & 246.4 & 206.8 \\
\hline Total & 2391.0 & 2053.3 & 1801.6 & 1798.6 & 1347.7 \\
\hline
\end{tabular}
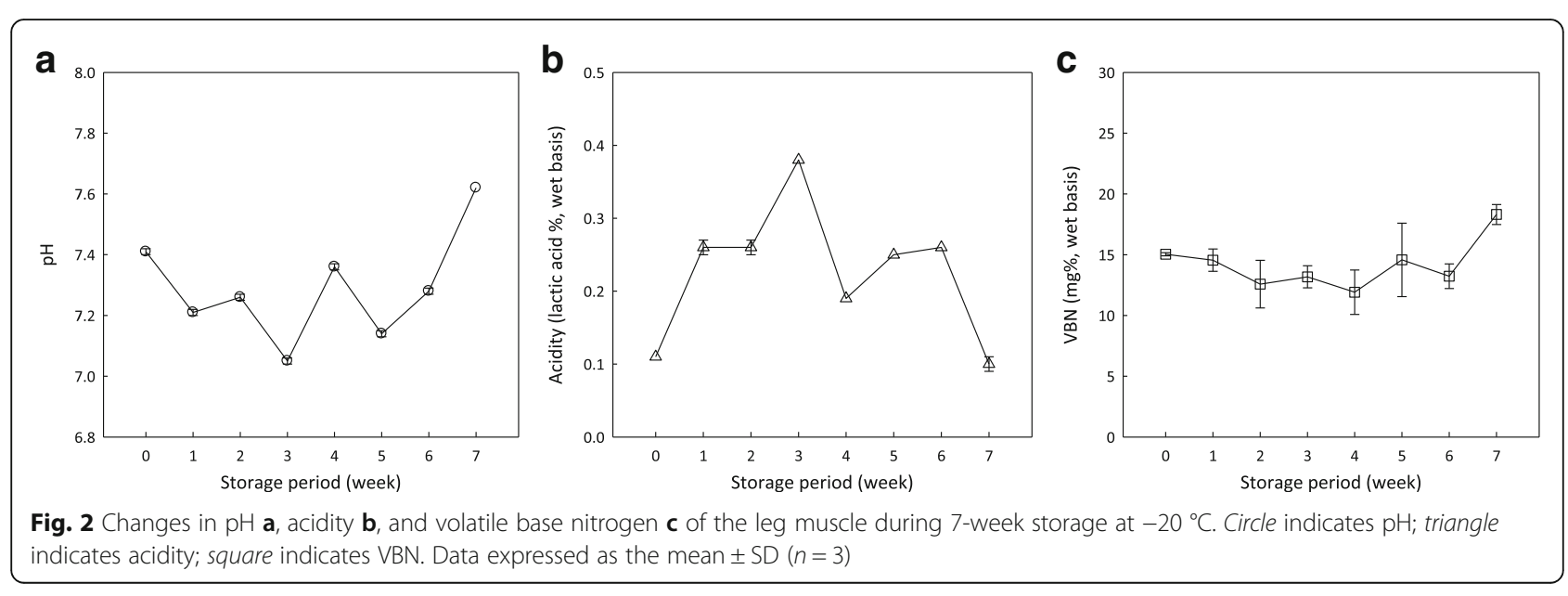

Fig. 2 Changes in $\mathrm{pH} \mathbf{a}$, acidity $\mathbf{b}$, and volatile base nitrogen $\mathbf{c}$ of the leg muscle during 7-week storage at $-20{ }^{\circ} \mathrm{C}$. Circle indicates $\mathrm{pH}$; triangle indicates acidity; square indicates VBN. Data expressed as the mean \pm SD $(n=3)$ isolated from the leg muscle and of arginase was dominant. This might explain well the noticeable loss of arginine from storage 3 -week in the present study. In a previous study for hard and soft mud crabs, the $\mathrm{pH}$ in the muscles decreased during 12-week storage at $-20{ }^{\circ} \mathrm{C}$, but according to the part of the muscles, a constant decrease was observed in claw muscle, while the $\mathrm{pH}$ in lump muscle temporary increased within 1and 2-week storage (Benjakul and Sutthipan 2009).

\section{Aerobic and lactic acid bacteria}

During the entire storage at $-20{ }^{\circ} \mathrm{C}$, the both aerobic and lactic acid bacteria were detected at low levels with the maximal cell counts of $2.5 \log \mathrm{CFU} \mathrm{g}{ }^{-1}$ wet basis). After fish dies, micro-organism might proliferate freely, but microbial contamination or the population in muscle much less than intestine and grows slowly before tenderization (Delbarre-Ladrat et al. 2006). In addition, the growth of general spoilage bacteria is inhibited in freezing condition (Srinivasan et al. 1997). Although there was not statistical significance $(P<0.05)$, the lactic acid bacteria slightly increased between 1 - and storage 3-week. These data matched with the increase of the acidity.

\section{Sensory test}

Appearance, flavor, and textural quality might be very important when consumer accept. Table 4 summarizes the change in sensory acceptability of the leg muscle during 7 -week storage. The texture was measured by finger pressing, and the overall acceptance indicates a consumption possibility with in ranges of point 4 to 7 . During the first 2-week storage, there were not changed in appearance, texture, flavor, and overall acceptance, but those decreased at storage 3-week. At 4-week storage, color, flavor, and overall acceptance was below 4 point, indicated that could not consume. 
Table 4 Change in sensory acceptability of the leg muscle during 7 -week storage at $-20^{\circ} \mathrm{C}$

\begin{tabular}{lllll}
\hline Storage period (week) & Appearance & Texture & Flavor & Overall acceptance \\
\hline 0 & $6.5 \pm 0.6^{\mathrm{a}}$ & $6.8 \pm 0.7^{\mathrm{a}}$ & $6.5 \pm 0.6^{\mathrm{a}}$ & $6.5 \pm 0.6^{\mathrm{a}}$ \\
1 & $6.4 \pm 1.1^{\mathrm{a}}$ & $6.5 \pm 0.6^{\mathrm{a}}$ & $6.3 \pm 0.5^{\mathrm{a}}$ & $6.5 \pm 0.3^{\mathrm{a}}$ \\
2 & $6.5 \pm 0.9^{\mathrm{a}}$ & $6.6 \pm 0.8^{\mathrm{a}}$ & $6.3 \pm 0.9^{\mathrm{a}}$ & $6.2 \pm 0.3^{\mathrm{a}}$ \\
3 & $4.4 \pm 1.1^{\mathrm{ab}}$ & $4.8 \pm 0.2^{\mathrm{ab}}$ & $4.3 \pm 0.2^{\mathrm{ab}}$ & $4.7 \pm 1.1^{\mathrm{ab}}$ \\
4 & $3.4 \pm 1.1^{\mathrm{bc}}$ & $4.3 \pm 0.6^{\mathrm{b}}$ & $3.5 \pm 1.0^{\mathrm{bc}}$ & $3.3 \pm 1.0^{\mathrm{bc}}$ \\
5 & $2.3 \pm 0.5^{\mathrm{bc}}$ & $2.8 \pm 0.1^{\mathrm{bc}}$ & $3.0 \pm 1.4^{\mathrm{bc}}$ & $2.9 \pm 0.9^{\mathrm{bc}}$ \\
6 & $2.4 \pm 0.8^{\mathrm{bc}}$ & $2.8 \pm 0.4^{\mathrm{bc}}$ & $2.4 \pm 0.5^{\mathrm{bc}}$ & $1.8 \pm 0.5^{\mathrm{c}}$ \\
7 & $1.3 \pm 0.5^{\mathrm{c}}$ & $1.8 \pm 1.5^{\mathrm{c}}$ & $1.8 \pm 1.0^{\mathrm{c}}$ & $1.5 \pm 0.7^{c}$ \\
\hline
\end{tabular}

Data expressed as the mean \pm SD $(n=3)$. Different types of small superscript letters indicate significantly differences $(p<0.05)$

From the results, the maximal storable period at $-20^{\circ} \mathrm{C}$ for muscle separation from the $C$. japonicus was suggested within 2 weeks and it was depended on the external factor such as discoloration than $\mathrm{pH}, \mathrm{VBN}$, and bacterial count. These results might be referred as basic data for approaches to solve quality loss occurred in non-thermal muscle separation.

\section{Conclusions}

In this study, the quality changes of the leg meat of red snow crab (C. japonicus) during freeze storage were investigated. During the storage, considerable loss of the leg muscle did not occur and microbiological risk was very low. In contrast, discoloration appeared at 2-week storage on around carapace and the leg muscle turned yellow at storage 3-week. In physiochemical parameters, protein and free amino acids gradually decreased with storage time, expected that proteolytic enzymes still activated at $-20{ }^{\circ} \mathrm{C}$. At 4 -week storage, the sensory acceptance dropped down below point 4 as low as inedible and notable inflection points in $\mathrm{pH}$ and acidity were observed. The volatile base nitrogen was low, though a little increase was recorded. These results suggested that the maximal storable period at $-20{ }^{\circ} \mathrm{C}$ of the raw material was within 2 weeks and it was depended on external factor such as the discoloration. The present study might be referred as basic data for approaches to solve quality loss occurred in non-thermal muscle separation.

\section{Abbreviations}

C. japonicus: Chionoecetes japonicus; C. opilio: Chionoecetes opilio; NHS: No heating separation

\section{Authors' contributions}

JYJ contributed to conduct the research and prepare the draft manuscript. MJJ contributed to conduct the physiochemical and sensory experiments. DSK and IHJ contributed to design the study and conduct the experiments. BMK contributed to monitor the experiments and finalize the manuscript. All authors read and approved the final manuscript.

\section{Acknowledgements}

This study was supported, in part, by grants from the KIMST (Korea Institute of Marine Science \& Technology Promotion), Fishery Commercialization Technology Development Program (GA142600-03), and we thank the institute for the support.
Availability of data and materials

Not applicable.

\section{Funding}

Not applicable.

Ethics approval and consent to participate

Not applicable.

Consent for publication

Not applicable.

Competing interests

The authors declare that they have no competing interests.

\section{Publisher's Note}

Springer Nature remains neutral with regard to jurisdictional claims in published maps and institutional affiliations.

\section{Author details}

'Division of Strategic Food Industry Research, Korea Food Research Institute, Seongnam 13539, Republic of Korea. ${ }^{2}$ Jeonbuk Institute for Bioindustry, Jeonju 54810, Republic of Korea. ${ }^{3}$ Department of Marine Food Science \& Technology, Gangneung-Wonju National University, Gangneung 25457, Republic of Korea.

Received: 9 April 2017 Accepted: 29 June 2017

Published online: 18 July 2017

\section{References}

Ahn JS, Kim H, Cho WJ, Jeong EJ, Lee HY, Cha YJ. Characteristics of concentrated red snow crab Chionoecetes japonicus cooker effluent for making a natural crab-like flavorant. J Kor Fish Soc. 2006;39:431-6.

AOAC. Official methods of analysis, 18th ed. Methods 925.45, 923.03, 976.05, 991. 36. Gaithersburg: AOAC International Publishing; 2005.

Benjakul S, Sutthipan N. Muscle changes in hard and soft shell crabs during frozen storage. LWT-Food Sci Technol. 2009;42:723-9.

Choi YJ, Jang MS, Lee MA. Physicochemical changes in kimchi containing skate (Raja kenojei) pretreated with organic acids during fermentation. Food Sci Biotechnol. 2016;25:1369-77.

Delbarre-Ladrat C, Chéret R, Taylor R, Verrez-Bagnis V. Trends in postmortem aging in fish: understanding of proteolysis and disorganization of the myofibrillar structure. Crit Rev Food Sci Nutr. 2006;46:409-21.

Feng J, Zhan XB, Zheng ZY, Wang D, Zhang LM, Lin CC. A two-step inoculation of Candida ethchellsii to enhance soy sauce flavor and quality. Int J Food Sci Tech. 2012:47:2072-8.

Gill T. Chapter 2. Nucleotide-degrading enzymes, Seafood enzymes. New York: Marcel Dekker Inc; 2000. p. 37-68.

Huss HH. Quality and quality changes in fresh fish, FAO fisheries technical paper 348. Rome: Food and Agriculture Organization of the United Nations; 1995.

Jun JY, Lim YS, Lee MH, Kim BM, Jeong IH. Changes in the physiochemical quality of sailfin sandfish Arctoscopus japonicus sauces fermented with 
soybean koji or rice koji during storage at room temperature. Korean J Fish Aquat Sci. 2016;49:101-8.

KFA. Korean fisheries yearbook. Seoul: Korea Fisheries Association; 2015.

Kim JM, Marshall MR, Wei Cl. Chapter 10. Polyphenoloxidase, seafood enzymes. New York: Marcel Dekker Inc; 2000. p. 271-315.

Kim HS, Park CH, Choi SG, Han BW, Kang KT, Shim NH, Oh HS, Kim JS, Heu MS. Food component characteristics of red-tanner crab (Chionoecets japonicus) paste as food processing source. J Korean Soc Food Sci Nutr. 2005;34:1077-81.

Kim BM, Jeong JH, Jung MJ, Kim JC, Jun KH, Kim DS, Lee KP, Jun JY, Jeong IH. Effects of freezing storage temperature and thawing time on separation of leg meat from red snow crab Chionoecetes japonicus. Korean J Fish Aquat Sci. 2015;48:655-60.

Kim BM, Park JH, Kim DS, Kim YM, Jun JY, Jeong IH, Nam SY, Chi YM. Effects of rice koji inoculated with Aspergillus luchuensis on the biochemical and sensory properties of a sailfin sandfish (Arctoscopus japonicus) fish sauce. Int J Food Sci Tech. 2016:51:1888-99.

Lorentzen G, Skuland AV, Sone I, Johansen JO, Rotabakk BT. Determination of the shelf life of cluster of the red king crab (Paralithodes camtschaticus) during chilled storage. Food Control. 2014;42:207-13.

Matsumoto M, Yamanaka H. Post-mortem biochemical changes in the muscle of tanner crab during storage. Nippon Suisan Gakk. 1992;58:915-20.

Miyagawa M, Tabuchi Y, Yamane K, Matsuda H, Watabe S, Hashimoto K, Katakai R, Otsuka Y. Change in the free amino acid profile of snow crab Chionoecetes opilio muscle during storage in ice. Agric Biol Chem. 1990;54:359-64.

NFRDI. Chemical composition of marine products in Korea. 2nd ed. Busan: National fisheries Research and Development Institute; 2009.

Park JH, Min JG, Kim TJ, Kim JH. Composition of food components between red-tanner crab, Chionoecetes japonicus and Neodo-Daege, a new species of Chionoecetes sp. Caught in the East Sea of Korea. J Korean Fish Soc. 2003;36:62-4.

Srinivasan S, Xiong YL, Blanchard SP. Effects of freezing and thawing methods and storage time on thermal properties of freshwater prawns (Macrobrachium rosenbergii). J Sci Food Agric. 1997;75:37-44.

Xu W, Yu G, Xue C, Xue Y, Ren Y. Biochemical changes associated with fast fermentation of squid processing by-products for low salt fish sauce. Food Chem. 2008;107:1597-604

\section{Submit your next manuscript to BioMed Central and we will help you at every step:}

- We accept pre-submission inquiries

- Our selector tool helps you to find the most relevant journal

- We provide round the clock customer support

- Convenient online submission

- Thorough peer review

- Inclusion in PubMed and all major indexing services

- Maximum visibility for your research

Submit your manuscript at www.biomedcentral.com/submit

) Biomed Central 